\title{
The Fall of The Princess: The Hidden Social Contract with The Formation of Psychosexual Identity and Un- conscious Mind of Women Through Fairy Tales
}

\author{
Esin KUMLU*
}

The Fall of The Princess: The Hidden Social Contract with The Formation of Psychosexual Identity and Unconscious Mind of Women Through Fairy Tales

\section{Abstract}

In this study, The Little Mermaid, Rapunzel, Sleeping Beauty, and The Twelve Dancing Princesses are analyzed comparatively to focus on how fairy tales affect the psychosexual identity and unconscious mind of women. The comparative reading of the texts illuminate the fact that fairy tales create a kind of hidden social contract between the society and the female world. Being captivated, being silent, the necessity of being beautiful, lack of freedom of speech, submissiveness and obeying the rules of the male world, the danger of rebellion are the items of the hidden social contract. The development of psychosexual identity and the unconscious mind of a woman are hidden in fairy tales.

Key Words : Fairy Tales, Women's Studies, Identity, Comparative Literature.
Prensesin Düşüşü: Kadın Psikoseksüel Kimliği ve Bilinçaltı Oluşumunun Masallar ile Gizli Anlaşması

Özet

Bu çalışma masalların kadın bilinçaltı ve psikoseksüel kimliği üzerindeki etkilerini vurgulamak üzere Küçük Deniz Kızı, Rapunzel, Uyuyan Güzel, 12 Dans Eden Prenses adlı masalları karşılaştırmalı bir perspektiften incelemektedir. Metinlerin karşılaştırmalı olarak ele alınması, masalların kadın dünyası ve toplum arasında bir çeşit gizli anlaşma yarattığı gerçeğini ortaya koymaktadır. Hapsedilme, sessizleştirilme, güzel olmanın zorunluluğu, ifade hakkı yoksunluğu, boyun eğme, erkek egemen toplumun kurallarına uyma baskısı ve isyan etmenin tehlikeli sonuçları gibi kavramları dayatan anlaşma, kadının bilinçaltının ve psikoseksüel kimliğinin gelişiminde masalların ne denli önemli bir rol oynadığını ortaya koymaktadır.

Anahtar Kelimeler : Masallar, Kadın Çalışmaları, Kimlik, Karşılaştırmalı Edebiyat.

\section{Introduction}

"I read a book and my life changed" is a classic but powerful way to underline how literary works can change one's life. It is a well-known fact that, what we read not only affects how we interpret the world but also our unconscious minds which build the psychosexual identity of an individual. ${ }^{1}$ When it comes to women and literature, the book which changes our lives is not a

\footnotetext{
*Esin KUMLU, Öğr.Gör.Dr., Dokuz Eylül Üniversitesi, İngilizce Bölümü, esinkumlu@yahoo.com

${ }^{1}$ The term unconscious was first used by Sigmund Freud in 1915. According to Freud "[e]verything that is repressed must remain unconscious; but ... the repressed does not cover everything that is unconscious. The unconscious has the wider compass...(Freud, 1915, p. 166) (qtd. Reith, In Akhtar \& O'Neil, 2013, p. 180). Freud underlines the fact that
} 
novel, a short story, etc., but a piece of literary work which dramatically shapes the formation of identity, decision making mechanism, therefore the entire life of a woman: fairy tales. For instance, The Little Mermaid (1837), Sleeping Beauty (1812), The Twelve Dancing Princesses (1812), and Rapunzel (1812) can be interpreted as psychological and social dynamics which may unconsciously transform the perspective that a woman has about life. The comparative analysis of the fairy tales indicate the reality that they somehow shape how a woman interprets the notion of beauty, marriage / motherhood, freedom, being active / passive in life and the limits which are set for a woman in social life. The common point of the selected fairy tales is the fact that all notions have turned into a kind of social castration for women. While in Sleeping Beauty and Rapunzel the submissive female role is rewarded, in the Little Mermaid and the Twelve Dancing Princesses the idea of freedom and independence is punished. The comparative analysis of the mentioned fairy tales underlines the fact that the unconscious mind of the child is formulated through the passive female role model who should not only be beautiful but also rich, married and a mother. As an example for that in this study, the comparative analysis of the fairy tales, aims to illuminate how fairy tales negatively transform the psychosexual identity and unconscious mind of women. It can be assumed that the symbolic language which is created through fairy tales dramatically shapes how a female child interprets social world, marriage, men, and the idea of beauty, happiness and wealth. Through this transformation, the female child symbolically makes a hidden social contract which calls for submissiveness.

Even the name 'fairy tale' takes us back to a magical realm which can be integrated into our childhood days. The significance of the situation starts at this point, the magical realm which is created through fairy tales somehow turns into a social and psychological realm which dramatically transforms the unconscious mind of the child, therefore, the psychosexual identity and the social role of the female body and psyche in a negative way. As underlined by Vanessa Joosen: "What children read is believed to have a substantial influence on the construction of their own identity, on their beliefs and expectations towards others, and on their conscious and unconscious associations" (2001, p. 51). The starting point of this discussion began in the twentieth century which was a turning point for the fairy tale studies. Marcia Lieberman's article "Some Day My Prince Will Come": Female Acculturation through the Fairy Tale (1972) can be interpreted as a silent rebellion against the secret codes of fairy tales which have tremendous effects upon society. Lieberman's article is indeed a response against Alison Lurie's point of view in “Fairy Tale Liberation" in the New York Review of Books. As underlined by Donald Haase,

\footnotetext{
the effects of the unconscious keeps continuing in social life even after repression. According to Lacan, "It is structured like a language." Therefore, it has the potential to affect an individual in various ways and which is possible to analyze. In this study, the term unconscious is used in order to highlight how the symbolic language that is used in fairy tales affect the psychology of the female mind through transforming the unconscious mind of women via hidden contracts which will be further discussed in following parts.
} 
"That article and its 1971 sequel, "Witches and Fairies, "argued that folktales and fairy tales can advance the cause of women's liberation, because they depict strong females. Together, Lurie's two articles took the position that the strong female characters could be found not only among the classic fairy tales but also among the much larger and more representative corpus of lesser-known tales"(Haase, 2004, p.1)2.

Lieberman's response to Lurie is quite significant to analyze the historical development of fairy tales and the interpretation of them in the twentieth and twenty-first century literary circle. Lurie, in her article, underlines that fairy tales “...prepare children for women's liberation, therefore, and to protect them against Future Shock, you had better buy at least one collection of fairy tales" (1970, p. 42). According to Lurie, fairy tales portray "a society in which women are as competent and active as men, at every age and in every class" (1970, p.42). As a response to this, Lieberman strictly supports the idea that in fairy tales:

"Girls win the prize if they are the fairest of them all; boys win if they are bold, active and lucky. If a child identifies with the beauty, she may learn to be suspicious of ugly girls, who are portrayed as cruel, sly, and unscrupulous in these stories; if they identifies with the plain girls, she may learn to be suspicious and jealous of pretty girls, beauty being a gift of fate, not something that can be attained" $(1972, p$. 385).

It is not that much difficult to agree with Lieberman as the classic fairy tales, which have been part of our lives regarding culture, language, color, race, etc., indicate the fact that female body and psyche have been trying to be transformed into a passive, silent, beautiful, married robot who should obey the rules of the male dominated discourse in order to be happy in life. Although Lurie defines this picture as a tool to help women from future shock, Lieberman defines this as a source of shock which freezes the psychosexual identity and unconscious mind of the female and alter it with the one which is offered by the dominant ideology of fairy tales. As underlined by Adrienne Rich, "[the] essential dichotomy: power/ powerlessness" (Rich, 1995, p. 64) forms the very basis of fairy tales. The powerful male characters and the powerless female characters unconsciously strengthen the power of the language which is the language of the future psychosexual identity and the unconscious mind of the female aura. The dominant ideology is coded and empowered through a symbolic language, which is used by fairy tales, has a stronger impact upon the child more than one can imagine. As highlighted by Eric Fromm,

\footnotetext{
${ }^{2}$ Lurie's position provoked Marcia R. Lieberman, who in 1972 published a forceful rebuttal titled "Some Day My Prince Will Come": Female Acculturation through the Fairy Tale." Lieberman was neither sympathetic to Lurie's main argument that fairy tales portrayed strong female characters nor receptive to her important qualification that liberating stories had been obscured by males who dominated the selection, editing, and publication of fairy tales. (Haase, 2004, p. 1)
} 


\section{Esin KUMLU}

"Symbolic language is a language in which inner experiences, feelings and thoughts are expressed as if they were sensory experiences, events in the outer world. It is a language which has a different logic from the conventional one we speak are the ruling categories but intensity and association. It is the one universal language the human race has ever developed, the same for all cultures throughout the history"'”'(1959, p. 7).

What is universal about fairy tales is the universality it promotes for all cultures in the world. The symbolic language it offers for the readers is

"[a] language in which we express inner experience as it were a sensory experience, as if it were something that was done to us in the world of things. Symbolic language is language in which the world outside is a symbol of the world inside, a symbol for our souls and our minds"(Fromm, 1959, p. 12).

The symbol for the soul, the psychosexual identity, and the symbol for the mind, the unconscious mind, become the locomotives of the development of the female child. ${ }^{3}$ The question which one needs to ask is how the symbolic language, of the fairy tales affects the child? As mentioned by Vanessa Joosen, "literature can change society for the better when it is written with the "right" ideological stance (2001, p. 55) ${ }^{4}$. The ideological stance in fairy tales unfortunately changes society in a negative way. The comparative analysis of The Little Mermaid, The Twelve Dancing Princesses, Rapunzel and Sleeping Beauty illuminates the reality that the psychosexual identity and the unconscious mind of the female child are negatively shaped by the ideology of the tales. ${ }^{5}$

To begin with, in The Little Mermaid, the female character is a beautiful mermaid who is entrapped under the sea world. She is forbidden to visit the outer world until she is 15 . She has a fish tail, which symbolizes not a freedom or originality but a kind of social castration which prevents her from walking. The ability of using the body freely is limited for The Little Mermaid. However, her life changes one day when she rescues a prince in the sea. She falls in love with him. As her world is different from his, she asks for help from the sea witch to be a real human to reach the

\footnotetext{
${ }^{3}$ The transformation of the unconscious is quite significant in one's life as “...when the unconscious is repressed and its content denied entrance into awareness, then eventually the person's conscious mind will be partially overwhelmed by derivatives of these unconscious elements, or else he is forced to keep such rigid, compulsive control over them that his personality may become severely crippled. But when unconscious material is to some degree permitted to come to awareness and worked through in imagination, its potential for causing harm-to ourselves or others-is much reduced; some of its forces can then be made to serve positive purposes.(Bettelheim, 1975, p. 7).

4 "The popular fairy tales of Lang and Disney, she argues, teach children "behavioral and associative patterns, value systems, and how to predict the consequences of specific acts or circumstances"(187) "( Joosen, 2001, p. 51)

5 "German pedagogue Otto F. Gmelin (1975), argued that fairy tales teach children aggression and fear and that (?) they promote sexism and capitalism." (quoted in Joosen, 2001, p. 52)
} 
prince. She is eligible to visit the outer world on condition that she cannot visit there again if she cannot be the wife of the prince. She sacrifices herself and visits the prince's palace. However, he has already planned to marry another girl. She has to turn back to the sea and is punished by the witch in order not to visit the world again. ${ }^{6}$ The story is same for the Twelve Dancing Princesses. The sisters try to escape from their father's palace each night in order to dance freely. The princesses' attempt to use their body freely is a common discourse of both tales. The sisters are finally captured by a man and their secret is resolved. The elder sister is punished by his father and she is forced to marry the man who has solved their secret. It can be assumed that if a woman wants to rebel, the result is not freedom but captivation and oppression. On the other hand, as for Rapunzel and the Sleeping Beauty, submission and passivity are rewarded. The hidden message is that, you can find your prince, if you obey the rules of society; silence, submission and passivity. While The Sleeping Beauty keeps sleeping, which is a symbol of passivity, Rapunzel accepts her captivity at a palace. As both fairy tales are resolved, the female characters are rewarded by a handsome prince. As is also mentioned by Helen Cixous:

"One cannot yet say of the following history "it's just a story." It's a tale still true today. Most women who have awakened remember having slept, having been put to sleep.

Once upon a time...once...and once again.

Beauties slept in their woods, waiting for princess to come and wake them up. In their beds, in their glass coffins, in their childhood forests like dead women. Beautiful, but passive; hence desirable: all mystery emanates from them"(1986, pp. 65-66).

Although the endings are different for all the protagonists, the princesses, are forced to become a member of the fairy tale club that calls for being beautiful, getting married and having a child. The fall of the Princess is not a fall into the arms of a prince but on ground, which is a harsh reality of social life.

\section{Facing the Barbie Complex: How Women are Entrapped by the Beauty Industry}

If one is asked to talk about beauty industry, she will probably talk about advertisements, magazines, television shows or social media which all support the need of having a kind of Barbie Doll look for women. When the roots of Barbie Doll-like beauty is analyzed, fairy tales can be interpreted as the first step, which secretly organizes a social contract with the female child: "If you are beautiful, you will win." The unconscious mind of the child will probably interpret this as "Beauty is the only key to happiness in this life." The hidden social contract with the psychosexual identity and the unconscious mind of the child will result in the need of being beautiful in life in order to be happy. Therefore, being not a Barbie doll is equal to unhappiness. That kind of an interpretation may form the very roots of how a child develops her identity not only as a woman but

\footnotetext{
${ }^{6}$ The Little Mermaid has different versions. The endings of the fairy tale differ according to its each.
} 


\section{Esin KUMLU}

also as an individual in social life. Therefore, it can be assumed that the roots of the social contract between a girl and Barbie doll beauty is hidden in the fairy tale discourse. ${ }^{7}$

In the Little Mermaid, Rapunzel, Sleeping Beauty and the Twelve Dancing Princesses, the discourse of the need of being beautiful is the common point of the female protagonists. As mentioned by Eric Hulsens, "Generation after generation this fairy tale teaches girls that what matters in life is to be beautiful and to wait for a prince"(234; my translation) (quoted in Joosen, 2001, p. 52-53). When the beginning of the fairy tales are analyzed, it can be assumed that almost all of them give the message of the necessity of being beautiful:

"Many years ago, deep at the bottom of the sea, stood the coral palace of the Mer-king.(Andersen, 2009, p. 1) $)^{8}$ He had six beautiful daughters. But the youngest mermaid was the prettiest"( LM 1).

"Once upon a time, there were a queen and a king. They reigned the country together. There were also fairies in the country in those days. (Grimm, 2016, p. 30) ${ }^{9}$ The queen had a baby and she was so beautiful that they couldn't stop looking at her. She was very beautiful. Her cheeks were redder than the wild roses on the palace walls" (SB 35).

"One day, "a king's son"(R 50) heard Rapunzel singing a song. He said "'Rapunzel, Rapunzel, let down your hair to me. I will climb with it" (Grimm, 2016, p.51). ${ }^{10}$

Suddenly, the prince hold her white soft hands and kissed them. Rapunzel went red.

"There was a king in a beautiful rich country. He had twelve beautiful daughters. They slept in twelve beds in on one room. They shared everything they had with

\footnotetext{
7 "The work of Carl Jung underpins so much current thinking about myth that it is worth outlining his position in some detail. The key to his theory of myth lies in his idea of a collective unconscious common to all, comprised of 'archetypes'(Sellers, 2001, p. 4). It can be asserted that, fairy tales act as myths which creates archetypal figures. The result of this is a common collective unconscious that shapes women.

${ }^{8}$ Quotations from The Little Mermaid will be hereafter cited as "LM" and parenthetical page numbers in the text. Andersen, H.C. (2009). The Little Mermaid. Ankara: Binbir Çiçek.

${ }^{9}$ Quotations from The Sleeping Beauty will be hereafter cited as "SB" and parenthetical page numbers in the text. Grimm, T. B. (2016) (Third Ed.) Sleeping Beauty. Grimm Tales. İstanbul: Sis. (30-36)

${ }^{10}$ Quotations from Rapunzel will be hereafter cited as " $R$ " and parenthetical page numbers in the text. Grimm, T. B. (2016) (Third Ed.) Rapunzel. Grimm Tales. İstanbul: Sis. (30-36)
} 
each other. When they went to bed, the doors were shut and locked up" (Grimm,2016, p. 9). ${ }^{11}$

The common point of all the fairy tales is the reality that they unconsciously code the female child with the idea that they are all the little princesses of a country which is ruled by their father as the king. This reminds the reader of Margaret Atwood's comment on this; "Did you believe that stuff when you were little? 'I did, I thought I was really a princess and I'd end up living in a castle. They shouldn't let kids have stuff like that"(1998, p. 55). The symbolic language which is used by fairy tales directly affects the child in a negative way. The child's brain codes itself with the idea that they are precious, beautiful and strong as they are the little princesses of a country. However, that kind of a social contract may result in unhappiness in their future lives. As is underlined by Simone De Beauvoir, "they must always be pretty in order to obtain love and happiness..."(Beauvoir, 1962, p. 33). Walker also "focus[es] on beauty as a girl's most valuable asset, perhaps her only valuable asset" (1996, p.188). The question is what will happen if a girl does not feel herself beautiful. Barbara G. Walker in her introduction to Feminist Fairy Tales(1996) defines this with the following words,

"Only to be decorative is the customary female function in these old stories. Girls without any beauty are also automatically without virtue, happiness, luck or love.... The message that such stories convey to girls is plain: Your looks are your only asset. Whatever else you might be or do doesn't count"(ix).

It can be assumed that the very roots of the beauty industry is hidden in fairy tales. The female psyche is entrapped by the symbolic language which is used in tales. The symbolic language will later become the symbol of unhappiness. The child will face the reality that she is not a beautiful princess of a king, she is not a member of a rich family, she does not live in a castle and thousands of handsome princes are not running after her. Therefore, the social contract which is made between the unconscious mind and the psychosexual identity of the female reader results in unhappiness. That kind of a dilemma can be found when a crucial question comes to mind: Where is the mother figure in fairy tales who can survive her daughter?

\subsection{Re-reading the Mirror Self and "The Second Sex" In Fairy Tales}

In her masterpiece The Second Sex, it cannot be a coincidence that Beauvoir talks about fairy tales in order to define how women have been tried to be controlled by "the male parameters" in social life. She defines the entrapment of all women by the patriarchal discourse, which defines women as the second sex, different, second class, entrapped, submissive, etc., through the female characters in fairy tales. She says: "Woman is the Sleeping Beauty, Cinderella, Snow White, she

${ }^{11}$ Quotations from The Twelve Dancing Princesses will be hereafter cited as "TD" and parenthetical page numbers in the text. Grimm, T. B. (2016) (Third Ed.) The Twelve Dancing Princesses. Grimm Tales. İstanbul: Sis. (30-36) 
Esin KUMLU

who receives and submits."(Beauvoir, 1962, p. 33). Beauvoir's definition of being a woman in terms of fairy tale characters indicates the starting point of the second sex dilemma, the first social contract between the male and the female: You are a beautiful princess who is rewarded by a handsome prince on condition that you obey the rules of the contract. Marriage, motherhood and submission are the prominent agendas of the contract and this contract can be best read through "the mother" in fairy tales.

Sleeping Beauty, The Little Mermaid, Rapunzel and The Twelve Dancing Princesses all begin with the powerful description of the 'father.' The father is the king, who rules a country. As a sole authority, the female protagonists are always defined through the father. They are the daughters of a king, not the princesses of a country. Therefore, they are socially existent on condition that they are under the umbrella of the father. In this problematic situation, the crucial point is that the mother is always absent at the beginning of the tales. It can be assumed that the mother is not socially accepted. The acceptance is later felt by two elements: marriage and motherhood. The mothers in the texts begin to be active when the mothers experience marriage and motherhood. In Sleeping Beauty, the queen is defined as 'lack.'

"They were married for a long time. But they had no children. As a result they were very unhappy. They thought that they were poorer than farmers. Because farmers had plenty of children, but they had none"(SB 30).

The mother is not only absent at the beginning of the story but also defined as lack as she does not have a child. In addition to the idea of beauty, the second social contract which is prepared by fairy tales is getting married and having a child. Therefore, the unconscious mind interprets this symbolic language as 'If you are not married and if you do not have a child, you are lack and you cannot be happy.' On the other hand, the psychosexual identity interprets this symbolic message as: social acceptance and feeling like a woman are only possible through marriage and motherhood.

"...the Dutch feminist publishing De Bonte Was (The Colored Wash) echoes Lieberman's critique of the fairy tale ending: "The fairy tale of marriage influences the life of all women, because from childhood onwards all of us-s have been presented with marriage as the future ideal(qtd. In Brunt 85)" (Joosen, 2001, p. 52).

The hidden social contract will immediately lead the child to code her body and soul as, being a happy, and a socially accepted woman is possible only through being a mother and a wife. In the story of Rapunzel the scenario is not different. The king and the queen do not have a child. "There were once a man and a woman. They were married for a long time. However, they had no children."(R 47). A magician comes to them and promises to help the queen to get pregnant on condition that she will take the child from them and protect her from all around the world. In this case, the woman is again lack from a different gaze. Although the queen achieves to have a baby, she cannot not raise her daughter as the little princess is captivated in a tower by the witch. This 
time, the mother becomes a mirror for the daughter, the submissive, silent, passive and obedient mother figure who sheds light upon the future of the princess, who will also probably be an obedient, captivated woman.

"Queens and mirrors...form a deadly combination for women, according to contemporary feminist critics. What we have found, on the contrary, is that mirrors indeed truth machines for German women writers. They show girls their future so that they can act autonomously..., mirror like surfaces reveal subterfuge, slavishness, and bad character in one's mate... They tell bitter truths about one's own worst emotions"(Blackwell, 2001,p. 7).

The mother, who does not exist at the beginning of the stories later becomes present, but that kind of a presence even intensifies her inexistence as she just exists to reflect the future life of her daughter. It can be assumed that the mother in the fairy tale acts "as a mirror of the forces limiting women" (Haase, 2004, p. 7).

The mother as the mirror self, is also significant in The Little Mermaid and The Twelve Dancing Princesses. In these fairy tales, the mother is not only socially and physically but also literally absent. This time, the protagonists do not have a mother and the lack of the mother is coded as a negative reality. Because the twelve sisters and the Little Mermaid do not have the opportunity of associating themselves with the mother figure, as they do not have the mirror self.

"In fairy tales and classical myth, the relationship between mother and daughter is rarely untroubled. The overwhelming impression of mother-figures given by the most recognizable version of our culture's most popular fairy tales and myths is of evil, absent or unpleasant mothers. Snow White's (step)mother tries to kill her; Cinderella's stepmother forces her to be a servant; Hansel and Gretel's (step)mother convinces their father to abandon them in the forest. Then there are the dead or absent mothers: the 12 dancing princesses have no living mother who can advise them; the Little Mermaid's mother is equally absent and unable to help.... "(Schanoes, 2016, p. 15).

At the end of the stories, it may not be a coincidence that both the mermaid and the sisters are punished unlike Rapunzel and the Sleeping Beauty. As the mirror self is absent, the little Mermaid and the sisters cannot associate themselves with the mother therefore, they rebel against limitations. The unknown future for them becomes the very reality of life; punishment. As exemplified by Vanessa Joosen,

"By addressing the unconscious of children in a symbolical language that is similar to dreams, fairy tales help the young deal with unspoken fears and desires, such as sibling rivalry and oedipal conflicts" (2011, p.124).

It is evident that what is unspoken in The Little Mermaid and The Twelve Dancing Princesses is the fact that rebellion against the limitations of social life will bring unhappiness. 


\section{Esin KUMLU}

\subsubsection{The Social Castration of the Female Body and Psyche}

At first sight, fairy tales promise a magical land where everything is built upon wealth, beauty, happiness and optimism. However, the female figures are socially castrated by the male world. For instance, The Little Mermaid is not eligible to see the world above the sea, The Twelve Dancing Princesses are not free to entertain, while Rapunzel and The Sleeping Beauty are not even permitted to have a contact with the social world as they are either captivated in a tower, as a kind of isolation from real life, or sleep like a dead. The reality behind being a princess unfortunately turns into captivation, submission, loneliness and passivity, which are all the results of the social castration which is formulated by the patriarchal discourse. Furthermore, the female characters seem to be always in 'lack' without having a prince in their lives. However, this cannot help them survive since marriage and motherhood will also lead them to a new vicious cycle which is another form of captivation.

It can be assumed that children socialize through what they read and see. Fairy tales have a very significant role in this process as whether parents or instructors are aware of the fact that or not, archetypal female behavior, femininity, psychosexual identity and the balance between body and soul are all affected, shaped and transformed through the discourse which is used in fairy tales. As underlined by Alison Lurie, "Analysis of the influence of the most popular children's literature may give us an insight into some of the origins of psychosexual identity" (1970, p.395) and The Little Mermaid is a very good example for that. In the story, the pretty princess Little Mermaid becomes the very symbol of captivation. She lives under the sea and the world above the sea is a kind of fairy land for her. "When you are fifteen, her grandmother said, "You may swim to the top and see these wonderful things for yourself." (LM 2). The first limit which a girl faces is age. She falls in love with the prince she rescues and wants to find him. "The little mermaid wanted to leave the sea. She wanted to be free of her fish tail, to be able to walk and dance!"(LM 12-13). Her fish tail symbolizes the social castration of the female body as her tail is a kind of excess for her which prevents her from walking and dancing. Walking and dancing are very powerful metaphors as the freedom to walk and dance is equal to the freedom of the female body and soul. That kind of a freedom means being active in social life. Therefore, the half female body becomes the very story of woman in social life. Liquidity, women, and sea are strong symbols to tell the story of women. Although the female body is inherently flexible, it is captivated by the male world as "[f]emale sexuality has always been conceptualized on the basis of masculine parameters" (Irigaray, 1993, p. 23).

The story of The Twelve Princesses is not different from The Little Mermaid. The Little Mermaid is prevented from experiencing the life above the sea, while the sisters went to bed "the doors were shut and locked up"(TD 9). They are no longer princesses of a rich country or the daughters of a king but captivated social figures. The case is not different for Rapunzel. She is shut in a tower. "The tower was in a forest and it had no stairs or door. But at the top of the tower, there was a little window" (R 50). The little window is the very symbol of the vision a woman can 
have in such an entrapment. How about the Sleeping Beauty? It is claimed that "A needle wound the king's daughter in her fifteenth year and she will fall down to the ground and die" (SB 32). So as to prevent this the Queen and the King forbid using needles in the country. However, one day when they are out of the palace, the beautiful princess is walking happily in the palace and she saw a woman sewing. She wanted to try to sew and all of a sudden she began to sleep and later all the court fell asleep as she was more helpless than the others. As "[t]he ultimate state of passivity" (Lurie, 1970, p. 388) is intensified through her sleep.

It can be assumed that the protagonists in fairy tales are no longer the protagonists as they are all shaped by outside forces such as the father, patriarchy, male parameters, etc. They are not in control of their lives as they are not free to choose. Rapunzel is shot in a tower by her family, the sisters are not permitted to go outside at night as they are locked up. The Sleeping Beauty is not even permitted to be alive, which is the deepest form of passivity, and the Little Mermaid is not permitted to experience the real world and forced to live under the sea. The common point of all these tales is the fact that female characters are forbidden to experience life. It is not possible for them to walk, dance or to be awake. The protagonists are not lonely and they are not the only ones who are affected by the social castration. The child who reads the tale will also become part of that cycle. They unconsciously think that they are the daughters of a king, as this is a natural process of life, and they should be either captivated or forced to sleep in order to be protected from the dangers of social life. Therefore, the hidden social contract with the unconscious mind is: you should be submissive, passive and loyal in order to be alive. The hidden social contract with the psychosexual identity is: being a woman means suppressing your body, the ways you entertain and being captivated, becoming the silent daughter of your father and giving the control of your life to the hands of the male authority. The unconscious mind will immediately codes this as "being a woman is equal to passivity.'

\section{The Princess does not Fall into the Hands of the Prince but to the Ground: The Tragic End- ing of Fairy Tales}

The beginnings are of course important but what determines the case is not the beginning but the end. In the Little Mermaid, Sleeping Beauty, Rapunzel and The Twelve Dancing Princesses the beginning of the stories sheds a light upon the sweet daughters of the kings who live in wealth and luxury. However, when the story unfolds, the luck of the princesses turns upside down. When the endings of the tales are analyzed, it becomes evident that the princesses do not fall upon to the hands of the handsome princess but to the ground, which is one of the very harsh realities of social life. Therefore, the fairy tale ends with tragedy. The comparative analysis of the selected tales underline the fact that the rebellious, active and self-reliant woman is punished while the submissive, passive and silent woman is rewarded by the male parameters. Even if the protagonist dares to rebel, like Rapunzel, who escapes with her beloved Prince, is punished at the end. Therefore, it can be assumed that, the discourse and the symbolic language which are used in fairy tales dramatically shape the unconscious mind of a child as the world they offer becomes the world in which they are punished. The prince is no longer the prince, the wealth is no longer the wealth and 


\section{Esin KUMLU}

the flexible body and mind which have the capacity to adapt themselves into different situations are no longer alive. Everything is dead, nothing is real and happiness is a remote island in an unknown land. The smooth arms of the prince is altered by the ground which is a marvelous tragic fall.

The endings of the fairy tales give an insight about being a woman in social life which is defined through the strict line between being a man and a woman:

"By the nineteenth century, the most influential body of popular tales, the Grimm's collection, labeled a girl bad and a boy bold for one the same deed (Bottigheimer, Grimm's Bad Girls). That curious polarization corresponded to social assumptions about gender in nineteenth-century Germany and in Western culture as a whole in that period.... tales contrasted sharply with German tale collections of the sixteenth century, which - like French, English, and Italian medieval tale collections..."(Haase, 2004, p. 1).

This is also evident in The Twelve Dancing Princesses, Rapunzel and Sleeping Beauty. The tales shape the gender roles through the hidden social contract which is made with the child. Luce Irigaray comments on the issue;

"The difference between the sexes ultimately cuts back through early childhood, dividing up functions and sexual roles: "maleness combines [the factors of] subject, activity...femaleness takes over [those of ] object and passivity"(Irigaray, 1993, p. 36).

What Irigaray underlines is the very root of fairy tales. The picture is always the same, the psychosexual identity of women is negatively transformed through the discourse of passivity. What if a woman wants to change this?

In the story of The Little Mermaid and The Twelve Dancing Princess, the protagonists dare to rebel against the patriarchal order and societal norms which are tried to be imposed on them. The Little Mermaid wants to rebel against the limitations of her life and wants to act like a real woman. She saw "a ship, bobbing up and down in the sea, was a young man. He seemed to be drowning!"(LM 6). She noticed a young man who was waiting to be rescued. She helped the young man and rescued him. "He was the most handsome young man she had ever seen"(LM 7). For the first time in a fairy tale the hero is a female and the man is helpless. The man needs help and the woman helps him survive. However, while the sea belongs to the home, protection, the world symbolizes social life, the male world. In order to be part of this social life, "The little mermaid wanted to leave the sea. She wanted to be free of her fish tail, to be able to walk and dance!"(LM 12-13). Her desire to use her body freely also means the desire to express oneself freely. The tail is a kind of excess which prevents her from being independent. She visits the sea-witch and asks for help to go to the world above the sea. At last, she says, "I will grant your wish, with one condition. You will be 
able to walk and dance, but you will not be able to talk and sing" (LM 14). It is evident that women have to choose from the list. There is a kind of hidden social contract between the society and the Little Mermaid. She can either walk and dance or talk and sing. It can be assumed that women are not permitted to use their body and mind freely at the same time. Using the body means the sacrifice of the freedom of speech. There is only one way for her to reach the prince; 'silence.' She has to admit to remain silent therefore she can use her body. Although a woman inherently, biologically, physically and psychologically has the capacity to both walk and dance, her gifts are reorganized by man. ${ }^{12}$ According to the contract, the Little Mermaid is punished. "Sadly, she entered the sea. She knew that now she would have to live beneath the sea forever" (LM 23). as the prince decides to marry another young lady. It is evident that the message behind the ending is if you try to rebel, you will be punished.' It is no longer possible for her to reach the world above the sea. Two different worlds can be interpreted as the inner world of a woman, the sea, and the world above the sea, social life and unfortunately, she is forbidden to enter into social life and is punished to live in her inner world. As the sea has always been associated with the feminine life as a symbol of liquidity, she is forced to turn back to the sea, a kind of mother's womb, the so-called protected life.

As for the twelve sisters in The Twelve Dancing Princesses, the ending is not different.. The sisters are part of a royal family, they live in a castle and their father is a king. So what is the problem? The sisters are shut and locked up each night and they want to rebel against this. Every night they achieve to escape from the castle in order to dance freely and "every morning the servants saw their shoes got worn out as if they danced all the nights. Nobody could find how it happened or where they were at nights"(TD 9). What binds The Little Mermaid and The Twelve Sisters is the fact that they both want to rebel against the physical and psychological limitations of being a woman. The fish tail is the symbol of physical captivation of women who are entrapped under a different world, which can be interpreted as 'home' which is separated from social life, just like the entrapment of the sisters at home. Their attempts to use their body freely is their rebellion. Wanting to dance is to use the body and the soul freely which is a form of physical and psychological freedom. The Little Mermaid also wants to dance in order to express herself to the Prince. It can be assumed that dancing, as a form of expression, means freedom of speech and act, as it gives a woman the power of expression. However, this cannot survive them from the tragic ending. The father of the Twelve Sisters wants to solve the secret as the power of his daughters to dance freely and their ability to escape from the castle every night indicates his lack of power.

\footnotetext{
12 "The story of the Little Mermaid reminds the reader of Simone De Beauvoir's comment" One is not born, but rather becomes, a woman. No biological, psychological, or economic fate determines the figure that the human female presents in society; it is a civilization as a whole that produces this creature, intermediate between male and eunuch, which is described as feminine.(1962, p. 9)
} 


\section{Esin KUMLU}

"Then the king announced that he wanted someone to solve the secret...He wanted to know where the princesses were dancing all nights. He also promised to give one of his daughter to the discoverer to be king after his own death"(TD 9).

"Well," said the old dame, "that is not a very hard task. Only take care not to drink any wine. Because one of the princesses will try to make you drunk. But you must pretend to drink it. And as soon as she leaves, you pretend to be fast asleep" (TD 10).

"Then she gave him a cloak and said, "As soon as you put on that cloak, you will then be able to follow the princesses wherever they go" (TD 10).

At the end, the soldier solves the secret and his reward is choosing one of the daughters as his wife. The King wants the soldier to take one of them as his wife. The soldier answers, "I am not very young, so I will have the eldest."(15). The hidden social contract in this context is the fact that the bride should be younger than the bride groom. In addition, the ending gives the message that if you rebel against the mail authority you will be punished just like the Little Mermaid. The decision making mechanism of both the sisters and the Mermaid is destroyed by the male authority as it is no longer possible for them to do what they want to do. The other invisible social contract is the reality that you should accept the husband which is offered by the male parameters. The eldest sister marries the soldier with discontent. However, the Grimm's said:

"They were married that very day and the soldier became king after his wife's father's death. In time the princess loved her husband. They lived happily hereafter"(TD 15).

It is evident that the hidden social contract gives the message that a woman can learn to love her husband in time and the choice of the male autonomy is always right. So just wait and be patient! The soldier in the tail even intensifies the male power as a symbol of the war between the male and the female. In addition, as the symbol of protection and security the soldier husband brings the so-called happiness.

It can be assumed that gender roles are shaped by the male power. The symbolic kings, who are indeed either the father or the husband in real lives, are the decision makers. The freedom to use your body freely or the freedom of idea or speech are even fantasies in fairy tales. It is evident that "romantic paradigms that profoundly influence women's fantasies and unconscious scenarios for their real lives" (Rowe, 1983, p. 69) are even not real in the tales. So, the idea of fairy tale as a land of magical happiness collapses as they are not the reflectors of optimism and hope but pessimism and unhappiness. The hidden social contract is the restricted female body and the unconscious mind which are programmed by the male power. If you rebel, you will be punished, if you want to act freely, you will be socially castrated, if you want to choose your partner, you cannot be happy, if you do not obey the choice of the father, you will lose, if you want to live in a different 
world, you will be isolated. The only world that a woman can live is the world of the father and the husband.

\subsection{The Problematic of Reward and Punishment}

While the Little Mermaid and the Twelve Sisters are punished due to their rebellious acts, as a matter of fact 'active,' attempts, Rapunzel and the Sleeping Beauty are rewarded due to their passive roles in the stories. The hidden social contract with the female body and unconscious mind is that 'If you obey and remain passive, happiness will be waiting for you.'13 The happiness which is promised is a kind of salvation by a handsome partner and a life-long happiness in marriage. The unconscious mind may immediately interpret this as 'You can be happy on condition that you remain passive and be obedient.' Another interpretation is 'Being active in life will bring unhappiness and loneliness.' One of the best examples of that kind of a social contract is seen in Rapunzel and the Sleeping Beauty. Both protagonists are the very center of passivity of the female body and the coded unconscious mind by male authority. Just like the previous protagonists, Rapunzel and Sleeping Beauty are the daughters of kings and they are members of a royal family. The common point of the princesses is the intensity of their passive ideology which is transmuted into the unconscious mind of the female child.

In the story of the Sleeping Beauty a prophecy transforms the life of the princess. It is believed that "A needle wound the king's daughter in her fifteenth year and she will fall down to the ground and die" (SB 32). The passivity of the Sleeping Beauty is the very root of the hidden social contract between the fairy tale and the reader. It can be asserted that 'sleeping' is the strongest symbol of passivity which is designed for women through fairy tales. As underlined by Eric Fromm;

"When we are awake, we are active, rational beings, eager to make an effort to get what we want and prepared to defend ourselves against attack. We act and we observe; we see things outside, perhaps not as they are, but at least in such a manner that we can use and manipulate them. But we are also rather unimaginative, and rarely - except as children or if we are poets - does our imagination go beyond duplicating the stories and plot that are part of our actual experience" (1959, p. 4).

Sleeping is indeed a human activity however, what is problematic in this case is the fact that the princess cannot wake up until the prince comes and kisses her. The sequence of the events is the entire story behind the hidden social contract:

\footnotetext{
${ }^{13}$ Bruno Bettelheim states that "'Safe' (Reconsider the use of ") stories mention neither death nor aging, the limits to our existence, nor the wish for eternal life. The fairy tale, by contrast, confronts the child squarely with the basic human predicaments. (Reconsider the use of ")(2010, p. 8). However, it can be asserted that most of the classic fairy tales emphasize the urgency of being safe through passivity, submissiveness and silence almost all of which supports the idea that safety is the only way for happiness in life. Therefore, it is not easy to agree with Bettelheim.
} 


\section{Esin KUMLU}

1. "He gave her a little kiss. Her lips were as a spring-time cherries"(SB 36).

2. "The moment he kissed the Sleeping Beauty, she opened her eyes and awoke and smiled upon him. The princess looked at her savior and loved him at that time"(SB 36).

3. "The fire in the kitchen blazed up. Everything in the palace started to move and turn back to the life. The clock started clicking again"(SB 36).

4. "And then the prince and the Sleeping Beauty were married and the king gave a great wedding feast. They lived happily together hereafter"(SB 36).

When the sequence is analyzed, it can be assumed that in order to be awake and alive, in this life you should learn to wait. Secondly, when you remain passive and obedient in life, your prince will come and this will be your reward in return for your submissiveness and patience. So do not dare to rebel. Thirdly, the life of a woman can begin with the existence of a man otherwise you will be a living dead. The last but not the least, happiness will be the ultimate result on condition that you accept the ideology of passivity, which is the hidden social contract with the society. It can be true to say that the unconscious mind of both the female child and the male child can easily be transformed through the symbolic language and the hidden social contract in fairy tales. The fairy tale "...which reaches the uneducated child" (Bettelheim 5-6) may have tremendous effects on the child more than one can guess. As mentioned by Carolyn G. Heilburn:

"One feels particularly the importance of not limiting the female imagination to female models. Bettelheim has shown how small boys can use the female model of helplessness in fairy tales to reduce their anxieties and unmentionable fears; similarly, young girls should be able to use male models to enhance their feelings of daring and adventure" (1993, p.147).

In the story of Rapunzel, just like in the Sleeping Beauty, the female is passive while the male is active. Rapunzel is shut in a tower by her family. "The tower was in a forest and it had no stairs or door. But at the top of the tower, there was a little window."(R 50) She has a very long hair, and she is rescued by a prince and gains her freedom. For Rapunzel marriage means salvation: "There is a young handsome prince with me now. I will go and marry him. I am bored here"(R 52). "Then they lived happy and contended for a long time afterwards"(R 54).

The hidden social contract in Rapunzel is; marriage is salvation, having long hair means being feminine, for protection man is a must in life, a woman is helpless and needs the strength of a man in order to survive. The last but not the least, happiness is promised at the end as marriage means happiness. Up to this point, the passivity of Rapunzel binds her with other female protagonists in fairy tales. 
“In 1974, for example, Andrea Dworkin's Woman Hating echoed Lieberman's thesis by asserting that fairy tales shape our cultural values and understanding of gender roles by invariably depicting women as wicked, beautiful and passive, while portraying man, in absolute contrast, as good, active, and heroic"(Haase, 2004, p. 1).

However, what is missing in the story of Rapunzel is the fact that when she decides to escape from the tower with the prince. Later she is punished by the magician and she is separated from the prince for a very long period of time. Later they achieve to come together. Therefore, the tale gives the message that if you dare to rebel against the rules you will either be separated from your loved ones or you will be unhappy. Luckily, Rapunzel survives but even the message at this point is the strength of the prince not the abilities of the princess.

\section{Conclusion}

Fairy tales have always been integrated into one's life through various ways. Whether it is through education, entertainment or literature, they somehow find a suitable area in child and adult world. When one thinks about the fairy tale world, Grimm's Brothers and Anderson come to mind immediately. As they are regarded the fathers of fairy tale writing, they have tremendous effects upon fairy tale scholarship. Their tales have transformed millions of children's lives through their language and the magical realm they have created for the reader. In relation with this, fairy tale scholarship have always been in touch with the symbolic language and the magical realm created by the Grimm's and Anderson. However, with the beginning of the twentieth century, fairy tale scholarship gained a new momentum and a totally different perspective. Starting with Marcia Lieberman's article “Someday My Prince Will Come. Female Acculturation through the Fairy Tales" (1972) literary scholars and psychologists have begun to interpret and analyze fairy tales through a different gaze. The sweet, magical realm which is surrounded by wealth, happiness, beauty, marriage, the ideal man, princesses and the idea of perfection have begun to be interpreted not as a safe world which enriches the child's imagination but a kind of danger which lures the unconscious mind of a child, especially the female child. As a result, scholars have begun to analyze the negative effects of fairy tales upon children. As an example for that in this study, the comparative analysis of the fairy tales, the Little Mermaid, Rapunzel, Sleeping Beauty, and the Twelve Dancing Princesses aim to illuminate how fairy tales negatively transform the psychosexual identity and unconscious mind of women. It can be assumed that the symbolic language which is created through fairy tales dramatically shapes how a female child interprets social world, marriage, men, and the idea of beauty, happiness and wealth. Through this transformation, the female child symbolically makes a hidden social contract which calls for submissiveness.

Almost all of the little girls have read fairy tales. Without a doubt, the Little Mermaid, Rapunzel, the Sleeping Beauty, and The Twelve Dancing Princesses are the most popular ones. What binds these fairy tales is the fact that their comparative analysis helps the reader to analyze the hidden social contract behind the magical realm. The first social contract between the female child and the society, male parameters, as underlined by Irigaray, is the Barbie Complex which is im- 


\section{Esin KUMLU}

posed upon the unconscious mind of the female child. Therefore, beauty is the first parameter which transforms the psychosexual identity of the female child. It can be assumed that, the very roots of the beauty industry is hidden in fairy tales. In The Little Mermaid, Rapunzel, the Sleeping Beauty, and The Twelve Dancing Princesses, the protagonists are all the little princesses of a country ruled by powerful kings. They are all defined as Barbie Doll-like girls who are defined through their beauty. The idea of beauty is the first hidden contract with the social world: If you are beautiful, you win! This contract is immediately interpreted by the unconscious mind as: If you are not beautiful, you cannot be happy, you cannot find the man of your life, and you cannot be the princess of your father. The psychosexual identity is of course affected by this discourse as the female identity is coded by the inescapable necessity of being beautiful. The danger of this discourse lies under the fact that the female mind begins to interpret everything through beauty. Therefore, the acceptance of one's self cannot be possible as beauty needs transformation of the body and outlook. One day the little girl, the reader, has to accept the reality that she is not a Barbie Doll, she is not the princess of a country which is surrounded by happiness and wealth. Therefore, the first contract will probably result in unhappiness.

The second hidden social contract with the formation of the psychosexual identity and the unconscious mind is: You must obey the rules of the male parameters. Therefore, you must get married and have a child. However, while you are waiting for this you should remain passive. Rapunzel and Sleeping Beauty are perfect examples for that. At the beginning of the stories, the queens cannot have a baby and they are regarded as 'lack', unhappy and half. The symbolic language underlines the necessity of getting married but it intensifies the necessity through motherhood. Social acceptance can only be possible through marriage and motherhood. In the case of The Twelve Dancing Princesses and The Little Mermaid, the picture is different as they are rebellious characters, they do not have a mother. However, they are punished at the end of their stories and this punishment builds a bridge between their mothers who do not even exist in the stories. The social acceptance and existence is only possible through obedience. Therefore, all the selected fairy tales underline the reality that obedience and submissiveness to the male parameters is a must. The unconscious mind immediately interprets this as: "You can be happy on condition that you are married and you have child." That is the reason why in the fairy tales all the princess get married at the end.

The third hidden social contract is related with silence. The Little Mermaid, Rapunzel, the Sleeping Beauty, and the Twelve Dancing Princesses are all forced to remain silent. The Little Mermaid is permitted to dance on condition that she does not speak, the Sleeping Beauty is permitted to live on condition that she sleeps, the Twelve Dancing Princesses are permitted to live in the castle on condition that they are locked up at nights, and Rapunzel is permitted to live on condition that she is captivated in a castle. Therefore, the unconscious mind interprets this as: "Being a woman means suppressing your body." Therefore, it defines womanhood as; submissiveness, captivation, silence and dependence. This contract dramatically transforms how a little girl forms 
her psychosexual identity. Therefore, being a woman becomes equal to passivity. The idea of passivity is related with waiting the ideal man through obeying the rules of male parameters. Therefore, freedom of speech, freedom of idea, freedom of choice, rebellion, or taking the responsibility of your life are even impossible to dream for the protagonists. Passivity becomes the inescapable fate for the princesses.

While the tales are interconnected with each other through various ways, the endings are needed to be analyzed differently. Although at first sight they seem to be different, the result is the same. While the beginning and the middle of the stories give the message to the unconscious mind that marriage, motherhood, obedience, passivity, dependence and lack of identity are necessary concepts in order to exist, the endings of the fairy tales give the message that "If you dare to rebel, you will be punished." It can be assumed that through the tone and the symbolic language of the tales, the female child is metaphorically marked by the male parameters: Unhappiness is inescapable when you dare to choose what you want. The story of Little Mermaid and Twelve Dancing Princesses are part of this dangerous discourse. For the first time, a female protagonist dares to rebel against the system. She is bold enough to try to save the prince and to reach him although she is not permitted to do that. At the end, she is punished and forced to live in the sea forever and not permitted to visit the world again. The Twelve Princesses' ending is not different. Their secret is solved, and the eldest sister is forced to marry the man, the soldier, who solves their secret. The other sisters are never permitted to dance at night and they are captivated in the castle. The ending for the sisters gives the message to the unconscious mind that rebellion or boldness are not even enough to win the battle. At the end, unhappiness, captivation and loneliness are waiting for you. On the other hand, if you obey the rules, you will marry the handsome prince and you will live happily hereafter.

It is evident that fairy tales are much more important in our lives than we think, especially for women. Their importance lies under the fact that they have the capacity to shape the formation of psychosexual identity and unconscious mind of a woman. Through the symbolic language they use, fairy tales strictly support the development of passive, submissive, dependent, silent, captivated women who cannot even dare to criticize the norms which are created by the male world. It can be assumed that the comparative analysis of fairy tales illuminates the hidden social contract between society and women. This gives power to readers, mothers, daughters and women in general to win the game. After realizing the false realities, they will be ready to shape their lives by themselves.

\section{References}

Andersen, H.C. (2009). The Little Mermaid. Ankara: Binbir Çiçek.

Atwood, M. (1998). Surfacing. New York: Anchor.

Beauvoir, S. (1962). The Second Sex. (Trans. H.M. Parshley). Four Square. 


\section{Esin KUMLU}

Blackwell, Jeannine (2001). "Introduction: The Historical Context of German Women's Fairy Tales." The Queens Mirror: Fairy Tales by German Women, 1780-1900. Ed. Shawn C. Jarvis and Jeannine Blackwell. Lincoln: University of Nebraska Press, 2001. p. 1-9.

Bettelheim, B. (2010). The Uses of Enchantment. The Meaning and Importance of Fairy Tales. Vintage: New York.

Cixous, H. (1986). "Sorties: Out and Out: Attacks /Ways Out / Forays." The Newly Born Women. Cathérine Clément. Trans. Betsy Wing. Minneapolis. U of Minnesota P. p. 63-132.

Fromm, E. (1959). The Forgotten Language. An Introduction to the understanding of Dreams, Fairy Tales and Myths. New York: Rinehart \& Co.

Grimm, T. B. (2016). (Third Ed.) Sleeping Beauty. Grimm Tales. İstanbul: Sis. 30-37.

Grimm, T. B. (2016). (Third Ed.) Rapunzel. Grimm Tales. İstanbul: Sis. 47-55.

Grimm, T. B. (2016). (Third Ed.) The Twelve Dancing Princesses. Grimm Tales. İstanbul: Sis. 9-16

Grimm, T.B. (2011). Grimm's Complete Fairy Tales. San Diego: Canterbury Classics.

Haase, D. (2004). "Feminist Fairy-Tale Scholarship." Ed. Fairy Tales and Feminism: New Approaches. Detroit: Wayne State UP. (Preface)

Heilburn, C. G. (1993). Reinventing Womanhood. 1979. New York: Norton.

Irigaray, L. (1993). This Sex Which is Not One. New York: Cornell UP.

Joosen, V. (2011). Critical \& Creative Perspectives on FAIRY TALES. An Intertextual Dialoguer between Fairy-Tale Scholarship and Postmodern Retellings. Detroit: Wayne State UP.

Lieberman, M. (1972). "Some Day My Prince Will Come": Female Acculturation through the Fairy Tale." College English, Vol. 34, No. 3 . p. 383-395.

Lurie, A.(1970). "Fairy Tale Liberation." The New York Review of Books, December 17. p. 42.

Reith, B. (2003). "Complementary Models of the Mind in Freud's "The Unconscious?" In Akhtar, S. \& O’Neil M. (Eds.) (2003). On Freud's “The Unconscious." London: Karnac.

Rich, A. (1995). Of Woman Born. Motherhood as Experience and Institution. New York: W.W. Norton Company.

Schanoes, V.L. (2016). Fairy Tales, Myth and Psychoanalytic Theory. Feminism and Retelling the Tale. New York: Routledge.

Walker, B. (1996). Feminist Fairy Tales. San Francisco: Harper. 
Rowe, K. E. (1983). "Fairy-born and human-bred: Jane Eyre's Education in Romance." Abel, Elizabeth, Marianne Hirsch, and Elizabeth Langland, eds. The Voyage in: Fictions of Female Development. Hanover, NH: UP of England. p. 69-89.

Sellers, S. (2001). Myth and Fairy Tale in Contemporary Women's Fiction. New York: Palgrave. 